\title{
Characterization of chitin synthase from Botrytis cinerea
}

\author{
Barry E. Causier, ${ }^{1}$ Richard J. Milling, ${ }^{2}$ Stephen G. Foster ${ }^{2}$ and \\ David J. Adams ${ }^{1}$
}

Author for correspondence: David J. Adams. Tel: +44532 335602. Fax: +44532335638.

1 Department of

Microbiology, University of

Leeds, Leeds LS2 9JT, UK

2 Schering Agrochemicals Ltd, Chesterford Park,

Saffron Walden, Essex

CB10 1XL, UK

\begin{abstract}
Chitin synthase in a microsomal preparation from Botrytis cinerea had an apparent $K_{\mathrm{m}}$ for UDP-N-acetylglucosamine of $2.0 \mathrm{mM}$ while nikkomycin $Z$ and polyoxin $D$ inhibited enzyme activity competitively with apparent $K_{\mathrm{i}}$ values of approximately $0.1 \mu \mathrm{M}$ and $6 \mu \mathrm{M}$ respectively. The organophosphorus fungicide edifenphos was a non-competitive inhibitor $\left(K_{\text {iapp }} 54 \mu \mathrm{M}\right)$. Preincubation of microsomes for $2 \mathrm{~h}$ at $25^{\circ} \mathrm{C}$ resulted in a maximum twofold stimulation of chitin synthase activity while preincubation with trypsin $\left(25 \mu \mathrm{g} \mathrm{ml}^{-1}\right)$ or cytosol ( $350 \mu \mathrm{g}$ cytosolic protein $\mathrm{ml}^{-1}$ ) for $10 \mathrm{~min}$ at $25^{\circ} \mathrm{C}$ resulted in approximately fourfold and 20 -fold increases in chitin synthase activity, respectively. A range of protease inhibitors reduced the degree of activation of microsomal chitin synthase by cytosol. Most potent were phenylmethanesulphonyl fluoride and chymostatin; these compounds completely inhibited activation of enzyme activity. Two fragments (approx. 600 bp; CHS1 and CHS2) were amplified from B. cinerea genomic DNA using degenerate PCR primers based on regions of complete amino acid homology between previously published chitin synthase gene sequences. When the DNA and predicted amino acid sequences of CHS1 were used to probe computer databases for related sequences, B. cinerea CHS1 was found to be most similar to CHS1 from Neurospora crassa.
\end{abstract}

Keywords: Botrytis cinerea, chitin synthase, zymogen, polymerase chain reaction, phylogenetic analysis

\section{INTRODUCTION}

Botrytis cinerea is an important plant pathogen with a wide host range which includes vines, ornamental plants and salad regetables (Groves et al., 1988). A number of fungicides, including systemic compounds (fungicides which enter the plant and are transported in the xylem and phloem), have been used extensively to control diseases caused by $B$. cinerea. Unfortunately, serious problems of resistance have arisen during the use of systemic botryticides (Adams, 1994). For example, strains of $B$. cinerea resistant to benzimidazoles and dicarboximides have caused major set-backs in the field (Pommer \& Lorenz, 1982; Leroux \& Clerjeau, 1985; Locke \& Fletcher, 1988). Consequently, there is an urgent requirement for new, broad-spectrum fungicides with novel modes of action which may permit more effective control of this plant disease.

The EMBL data library accession number for the nucleotide sequence reported in this paper is: $X 77937$ B. cinerea (SCHBC1) CHS1 gene.
Although some antifungal compounds disrupt fungal cell wall biosynthesis (Gooday, 1990) it is unlikely that the potential of the cell wall as a target for fungicides has been fully realized. Currently, there is a paucity of information on the regulation of cell wall biosynthesis in agriculturally important fungal pathogens. Chitin, a $(1 \rightarrow 4) \beta$ polymer of $N$-acetylglucosamine (GlcNAc), is a major structural component of the cell walls of most fungi, including $B$. cinerea (Gooday \& Trinci, 1980; Backhouse \& Willets, 1984). The enzyme chitin synthase (EC 2.4.1.16) catalyses the production of this macromolecule by polymerization of GlcNAc from the activated precursor UDPGlcNAc. There is now compelling evidence that chitin synthase isozymes play a fundamental role during cell division and morphogenesis in fungi (Shaw et al., 1991; Yarden \& Yanofsky, 1991; Cabib et al., 1992; Chen-Wu et al., 1992). Chitin is not found in green plants or vertebrates (Gooday, 1990). Therefore, chitin synthase and those cellular mechanisms which regulate the activity of this enzyme may present attractive targets for novel fungicides which lack host toxicity and toxicity to mammals and other animals. 
Chitin synthase has been isolated from a wide range of fungal species and the enzymes characterized in detail (Cabib, 1987). At least three chitin synthase genes and gene products have been identified in Saccharomyces cerevisiae and genes for chitin synthase have been identified in several other fungi (Yarden \& Yanofsky, 1991; Bowen et al., 1992; Chen-Wu et al., 1992). In contrast, littlc: information is available on the properties of chitir. synthase from plant pathogens (Hori et al., 1971, 1974a, b: Flemming et al., 1982; Cohen et al., 1986; Binks et al.. 1991). The aim of the current study was to undertake a detailed characterization of chitin synthase from $B$. cinerea. Ultimately, the enzyme will be used to determine the potential of mechanisms which regulate chitin synthase in vivo as targets for novel fungicides.

\section{METHODS}

Materials. Unless otherwise indicated, all chemicals were of Analar grade and were obtained from BDH, and all biochemicals were purchased from Sigma. Media were obtained from Oxoid. Nikkomycin Z and polyoxin D were obtained from CalbiochemNovabiochem. Edifenphos was provided by Schering Agrochemicals. All detergents with the exception of digitonin, sodium cholate and W-1 (Sigma) and Mega 9 (OXYL-GmbH), were purchased from Boehringer Mannheim. Radiochemicals were purchased from Amersham

Organism and culture conditions. $B$. cinerea (field isolate designated $\mathrm{SCHBC1}$ ) was maintained on plates of Potato Dextrose Agar (PDA; $39 \mathrm{~g} \mathrm{l}^{-1}$ ) at room temperature under daylight conditions and sub-cultured every $7-10 \mathrm{~d}$. Spores were harvested by washing the surface of the culture with sterile Tween $20(0.5 \%, \mathrm{v} / \mathrm{v} ; 10 \mathrm{ml})$. Spore suspensions were filtered through glass wool (pre-washed with distilled water) and the filtrates pooled. The resultant spore suspension was used to inoculate Malt Extract $(2 \%, \mathrm{w} / \mathrm{v} ; 500 \mathrm{ml})$ to a final concentration of approximately $2 \times 10^{6}$ spores $\mathrm{ml}^{-1}$ (measured microscopically using the Improved Neubauer Counting Chamber; Weber). Cells were shaken (100 r.p.m.) and incubated at $25^{\circ} \mathrm{C}$. After $16 \mathrm{~h}$ the culture was in the mid-exponential phase of growth and germlings were harvested by centrifugation in an MSE Mistral 6L centrifuge at 3000 r.p.m. for $15 \mathrm{~min}$ and washed once, by centrifugation, in cold $\left(4^{\circ} \mathrm{C}\right)$ homogenization buffer (50 mM Bis-Tris pH 6.5, 0.25 M sucrose, $1 \mathrm{mM}$ EDTA).

Disruption of cells and centrifugation of lysate. All operations were performed at $4{ }^{\circ} \mathrm{C}$. Germlings (approx. $20 \mathrm{~g}$ wet weight) were resuspended in homogenization buffer $(15-20 \mathrm{ml})$ and mixed with glass beads ( $15 \mathrm{ml} ; 0.5-0.75 \mathrm{~mm}$ diameter) in $50 \mathrm{ml}$ bottles. Cells were homogenized for $8 \times 30 \mathrm{~s}$ at 4000 r.p.m., with intervals of $30 \mathrm{~s}$ for cooling, in a Braun MSK cell homogenizer. The homogenate was centrifuged at $9000 \mathrm{~g}\left(r_{\mathrm{av}}\right.$, $6.98 \mathrm{~cm}$ ) for $20 \mathrm{~min}$ in a Sorvall RC-5B superspeed centrifuge with SS-34 rotor. The supernatant was centrifuged at $144800 \mathrm{~g}$ $\left(r_{\mathrm{av}}, 8.1 \mathrm{~cm}\right)$ for $1 \mathrm{~h}$ in a Sorvall OTD65B ultracentrifuge with TFT 50.38 rotor to pellet the microsomal fraction. The supernatant was stored at $-20^{\circ} \mathrm{C}$ as the cytosolic fraction and the pellet was washed once in $50 \mathrm{mM}$ Bis-Tris ( $\mathrm{pH} \mathrm{6.5).} \mathrm{The}$ supernatant was discarded and the microsomal fraction resuspended in $50 \mathrm{mM}$ Bis-Tris buffer ( $\mathrm{pH} \mathrm{6.5)}$ to a final protein concentration of $0.5 \mathrm{mg} \mathrm{ml}^{-1}$, and stored at $-20{ }^{\circ} \mathrm{C}$.

Enzyme assays. The chitin synthase assay was based on the method of Dickinson et al. (1991) with modifications. Unless otherwise stated the reaction mixture $(50 \mu \mathrm{l})$ contained micro- somal fraction $(10 \mu \mathrm{l})$ and $40 \mathrm{mM}$ Tris $/ \mathrm{HCl}(\mathrm{pH} 7.5), 6 \mathrm{mM}$ $\mathrm{MnCl}_{2}, 32 \mathrm{mM}$ GlcNAc and $1 \mathrm{mM}$ UDP-GlcNAc containing $9 \mathrm{nCi}(333 \mathrm{~Bq})$ UDP-[ $\left.{ }^{14} \mathrm{C}\right] \mathrm{GlcNAc}\left(272 \mathrm{mCi} \mathrm{mmol}^{-1} ; 10 \cdot 1 \mathrm{GBq}\right.$ $\mathrm{mmol}^{-1}$ ). Incubations were at $25^{\circ} \mathrm{C}$ for $60 \mathrm{~min}$. The reaction was stopped by a further incubation at $100{ }^{\circ} \mathrm{C}$ for $2 \mathrm{~min}$. The reaction mixture was filtered through glassfibre filter paper (Whatman GF/F glass microfibre filters; $2.5 \mathrm{~cm}$ diameter, $0.7 \mu \mathrm{m}$ pore size) pre-soaked in distilled water for $60 \mathrm{~min}$. The reaction tube was washed twice with $50 \mu \mathrm{l}$ aqueous Triton $\mathrm{X}$ $100(1 \%, v / v)$, and the washings filtered. Finally, the filter paper was washed with $10 \mathrm{ml}$ distilled water. The filter papers were placed in $4 \mathrm{ml}$ scintillant (Optiphase 'Safe', LKB Scintillation Products) and radioactivity measured in an LKB Wallac Rackbeta 1217 liquid scintillation counter.

Chitinase, $\beta$-N-acetylglucosaminidase and lysozyme were assayed as described by Dickinson et al. (1989), Rast et al. (1991) and Lundblad et al. (1974), respectively.

Protein concentration was determined by the method of Bradford (1976) using bovine serum albumin as standard.

Characterization of the chitin synthase reaction product. Chitin synthase reaction mixtures $(50 \mu \mathrm{l})$ containing microsomes $(10 \mu \mathrm{l})$ were incubated at $25^{\circ} \mathrm{C}$ for $60 \mathrm{~min}$. One of the following solutions $(50 \mu \mathrm{l})$ was added: $50 \mathrm{mM}$ potassium phosphate, $\mathrm{pH} 6.0$ (buffer A); 0.05 units of chitinase from Streptomyces griseus (Sigma, product no. C1525) in buffer A; 0.05 units of chitinase boiled for $3 \mathrm{~min}$ in buffer $A ; 11.6 \mathrm{M} \mathrm{HCl} ; 2 \mathrm{M} \mathrm{KOH}$. Reaction vessels were incubated for $1 \mathrm{~h}$ at $100^{\circ} \mathrm{C}(\mathrm{KOH})$ or shaken (160 r.p.m.) for $20 \mathrm{~h}$ at $20^{\circ} \mathrm{C}$. Incubations were filtered and radioactivity measured as described above.

Effect of trypsin on chitin synthase activity. Equal volumes $(50 \mu \mathrm{l})$ of the microsomal fraction $\left(0.5 \mathrm{mg}\right.$ protein $\left.\mathrm{ml}^{-1}\right)$ and trypsin in $50 \mathrm{mM}$ Bis-Tris, $\mathrm{pH} \mathrm{6.5,} \mathrm{were} \mathrm{mixed} \mathrm{and} \mathrm{incubated}$ for $10 \mathrm{~min}$ at $25^{\circ} \mathrm{C}$. Soybean trypsin inhibitor $(25 \mu \mathrm{l})$ was added at twice the trypsin concentration. Ten microlitres of the final mixture was used as enzyme preparation in the chitin synthase assay.

Effect of cytosol on microsomal chitin synthase. Cytosol $(16 \mathrm{ml})$ was concentrated by ultrafiltration using a Centricon 10 microconcentrator (Amicon) and resuspended to a concentration of $0.7 \mathrm{mg}$ protein $\mathrm{ml}^{-1}$ in $50 \mathrm{mM}$ Tris, $\mathrm{pH} \mathrm{7.5}$. Equal volumes $(25 \mu \mathrm{l})$ of a microsomal suspension $(0.5 \mathrm{mg}$ protein $\mathrm{ml}^{-1}$ ) and cytosol, or cytosol diluted in $50 \mathrm{mM}$ Tris, $\mathrm{pH} 7 \cdot 5$, were mixed and incubated at $25^{\circ} \mathrm{C}$ for $10 \mathrm{~min}$. Ten microlitres of the mixture was used in a standard assay for chitin synthase activity. In control incubations, cytosol was replaced with $50 \mathrm{mM}$ Tris, $\mathrm{pH} 7 \cdot 5$.

Effect of protease inhibitors on the activation of chitin synthase by cytosol. One of the following protease inhibitors was included in incubations of microsomes with concentrated cytosol (final inhibitor concentration indicated in parentheses): phenylmethanesulphonylfluoride(PMSF $; 0.5 \mathrm{mM}$ ), benzamidine $(1 \mathrm{mM})$, aprotinin $\left(0.3 \mu \mathrm{g} \mathrm{m}^{-1}\right)$, chymostatin $(0.1 \mathrm{mM})$, leupeptin $(0.1 \mathrm{mM})$, antithrombin III $\left(0.013 \mu \mathrm{g} \mathrm{ml}^{-1}\right)$, lima bean trypsin inhibitor $\left(0.3 \mu \mathrm{g} \mathrm{m}^{-1}\right)$, soybean trypsin inhibitor $\left(0 \cdot 3 \mu \mathrm{g} \mathrm{ml}^{-1}\right)$, EDTA $(1 \mathrm{mM}), 1,10$-phenanthroline $(5 \mathrm{mM})$, cystatin $\left(0 \cdot 3 \mu \mathrm{g} \mathrm{ml}^{-1}\right)$, or pepstatin A $(0.01 \mathrm{mM})$. Protease inhibitors were used at concentrations described previously as effective for the inhibition of specific classes of proteases (Beynon \& Salvesen, 1989). The inhibitors were also included in control incubations.

Isolation of genomic DNA from B. cinerea. The method was based on that of Murray \& Thompson (1980) with the following modifications: freeze-dried germlings $(500 \mathrm{mg})$ were re- 
suspended in extraction buffer $(15 \mathrm{ml})$ which included RNase $\left(40 \mu \mathrm{g} \mathrm{ml}^{-1}\right)$ and proteinase $\mathrm{K}\left(1 \mathrm{mg} \mathrm{ml}^{-1}\right) ; 50 \mathrm{mM}$ Tris $/ \mathrm{HCl}$, $\mathrm{pH} 8.0$, cetyl trimethylammonium bromide $(1 \%, \mathrm{w} / \mathrm{v}), 10 \mathrm{mM}$ ED'TA $(30 \mathrm{ml})$ was added to the aqueous phase $(15 \mathrm{ml})$ following the second chloroform/octanol extraction, the DNA was precipitated with ammonium acetate/ethanol, washed with ethanol $(70 \%, v / v)$, dried briefly under vacuum and resuspended in TE buffer $(5 \mathrm{ml})$.

PCR amplification of genomic DNA. Incubations were as described by Bowen et al. (1992) with modifications. Briefly, each reaction $(100 \mu \mathrm{l})$ consisted of 2.5 units Taq DNA polymerase, $20 \mathrm{nmol}$ of each dNTP, $10 \mathrm{mM}$ Tris/ HCl, pH 8.3, $50 \mathrm{mM} \mathrm{KCl}$, gelatin $\left(0 \cdot 1 \mathrm{mg} \mathrm{ml}^{-1}\right), 2 \mathrm{mM} \mathrm{MgCl}_{2}$, genomic DN ( $100 \mathrm{ng}$ ) and $25 \mathrm{pmol}$ of each primer (supplied by British Biotechnology). The primers used were as follows:

(A) .TG AAG CTT ACA ATG TAT AAT GAG GAA-3

$\begin{array}{lllll}G & C & C & A & T \\ C & & & & C \\ & & & & G\end{array}$

(B) '-GTT CTC GAG CTT GTA CTC GAA GTT CTG-3

$\begin{array}{llllllllll} & \mathrm{T} & \mathrm{A} & \mathrm{T} & \mathrm{A} & \mathrm{A} & \mathrm{T}\end{array}$

Forty cycles were run consisting of a $94^{\circ} \mathrm{C}, 1$ min step, a $50{ }^{\circ} \mathrm{C}$, $1 \mathrm{~min}$ step and a $72^{\circ} \mathrm{C}, 3 \mathrm{~min}$ step using an Omnigene Temperature Cycler (Hybaid). The conserved sequences encoded by the primers are not included in the analysed sequences.

Cloning using the pCRII vector and preparation of plasmid DNA from transformed $\boldsymbol{E}$. coli. The TA cloning system (Invitrogen Corporation) and Qiagen Hi Purity 'Plasmid' kit werc used in accordance with the manufacturers' instructions.

DNA sequencing. PCR products were sequenced by the method of Sanger et al. (1977) using the Sequenase kit (version 2.0; United States Biochemical) and $\left[{ }^{35} \mathrm{~S}\right] \mathrm{d} A \mathrm{TP} \alpha \mathrm{S}$. Several sequencespecific primers were constructed by Dr G. D. Elliott, Department of Microbiology, University of Leeds.

Analysis of DNA sequences. The entire DNA sequence of the $B$. cinerea CHS1 fragment was used to probe the GenBank (release 77.0) and EMBL (release 35) databases using the FASTA program. The amino acid sequence of the $600 \mathrm{bp}$ fragment was derived using the DNAsis program (Hitachi Software Engineering (Co.) and used to probe the Owl database (version 20.1) for related sequences, using a Sweep program generated with Sooty. The amino acid sequences were aligned and a phylogenetic tree generated using Clustalv (Higgins et al., 1991). FASTA, Sooty, Sweep and Clustalv were run on the Biovax system at the Department of Biochemistry and Molecular Biology, University of Leeds.

\section{RESULTS}

\section{Isolation and analysis of nucleic acids}

The PCR primers used during the present study were based on regions conserved in S. cerevisiae CHS1 and CHS2, and Candida albicans CHS1. Therefore, the two fragments (approximately $600 \mathrm{bp}$ ) amplified from $B$. cinerea genomic DNA using these primers were designated CHS1 and CHS2 [the latter was described previously as 'CHS3' (Causier, 1993)]. The CHS1 fragment was completely sequenced (Fig. 1). Comparison with the partial sequence of the CHS 2 fragment $(133 \mathrm{bp}$, data not shown) suggested that the CHS1 and CHS2 fragments were from similar but distinct genes. The DNA sequence of CHS1 was used to probe the GenBank and EMBL databases for related sequences. Of 34 chitin synthase sequences identified, CHS1 from Neurospora crassa was most closely related to $B$. cinerea CHS1 $(74.7 \%$ identity for an overlap of 475 nucleotides). Similarly, when the predicted amino acid sequence of $B$. cinerea CHS1 was used to probe the Owl database, the deduced gene product from $B$. cinerea was most closely related to the predicted amino acid sequence for $N$. crassa CHS1 $(85.7 \%$ identity for an overlap of 161 amino acids). When the predicted amino acid sequences retrieved from the database were aligned and used to generate a phylogenetic tree, the sequences were divided into three groups (data not

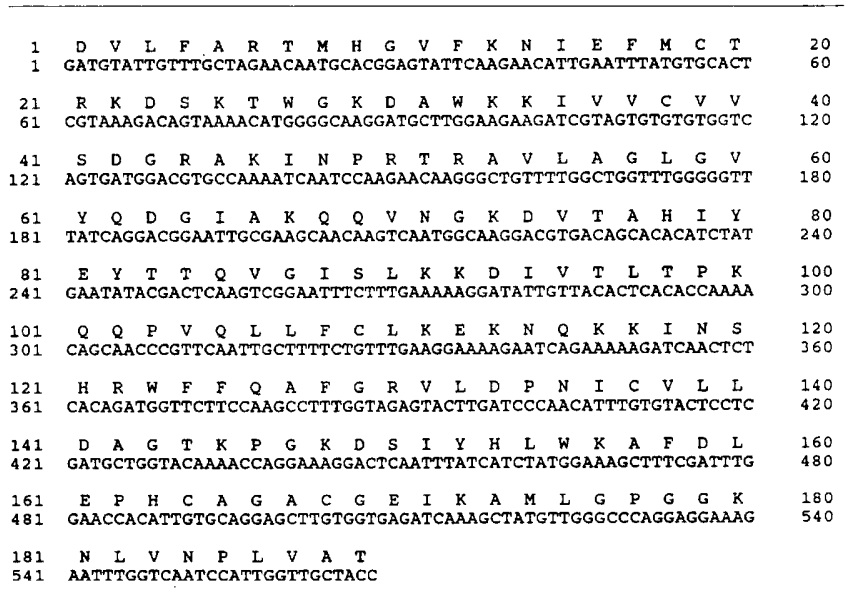

Fig. 1. The nucleotide and predicted amino acid sequence of the CHS1 fragment from $B$. cinerea.

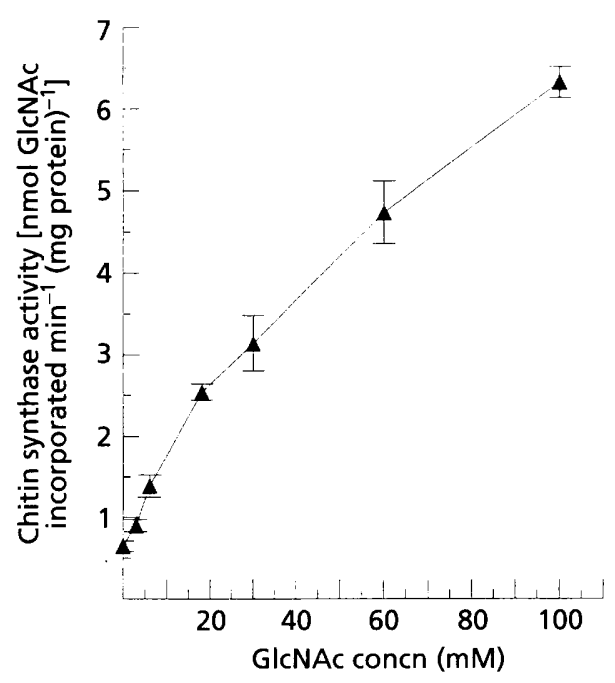

Fig. 2. Effect of GICNAC on chitin synthase activity. Values shown are the means of three experiments \pm SEM. 


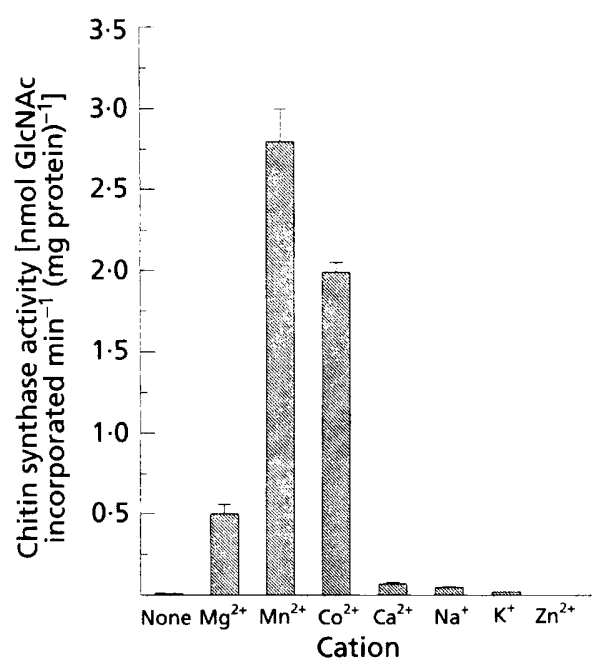

Fig. 3. Effect of cations (chloride salts, $6 \mathrm{mM}$ ) on chitin synthase activity. Values shown are the means of three experiments \pm SEM.

shown). Bootstrap analysis of the phylogenetic data demonstrated, in $100 \%$ of trials, that CHS1 from $B$. cinerea was grouped with CHS1 from $N$. crassa.

\section{Properties of the microsomal chitin synthase preparation}

Plots of product formed as a function of time $(0-3 \mathrm{~h})$ and rate of reaction against enzyme concentration $(0-2 \mathrm{mg}$ protein $\mathrm{ml}^{-1}$ ) were straight lines (data not shown). Lineweaver-Burk analysis yielded an apparent $K_{\mathrm{m}}$ of $2.0 \mathrm{mM}$ for UDP-GlcNAc and the apparent temperature optimum was $35^{\circ} \mathrm{C}$ (data not shown). Free GlcNAc stimulated enzyme activity (Fig. 2), which was dependent upon the presence of a divalent cation. $\mathrm{Mn}^{2+}$ was most effective (Fig. 3).

The reaction product was identified as chitin on the basis of the following properties: (a) incubating it with chitinase ( 0.025 units), but not boiled chitinase, for $20 \mathrm{~h}$ at $20{ }^{\circ} \mathrm{C}$ gave $98 \%$ degradation to soluble sugars; (b) $70 \%$ of the product was hydrolysed when treated with concentrated hydrochloric acid $(5 \cdot 8 \mathrm{M})$; and (c) the product was insoluble in $\mathrm{KOH}(1 \mathrm{M})$.

Microsomal and cytosolic preparations contained chitinase $\left[0.02\right.$ and $0.2 \mathrm{pmol}$ GlcNAc released $\min ^{-1}(\mathrm{mg}$ protein $)^{-1}$, respectively] and $\beta$ - $N$-acetylglucosaminidase $\left[0.3\right.$ and $5 \mu \mathrm{g}$ 4-nitrophenol released $\mathrm{min}^{-1}$ ( $\mathrm{mg}$ protein $)^{-1}$, respectively] activities. Lysozyme activity was not detected in microsomal or cytosolic preparations.

\section{Effect of nikkomycin Z, polyoxin D, UDP and edifenphos on microsomal chitin synthase}

The nucleoside-dipeptide antibiotics nikkomycin $\mathrm{Z}$ and polyoxin $\mathrm{D}$ were potent, competitive inhibitors of enzyme activity with apparent $K_{\mathbf{i}}$ values of approximately $0 \cdot 1 \mu \mathrm{M}$
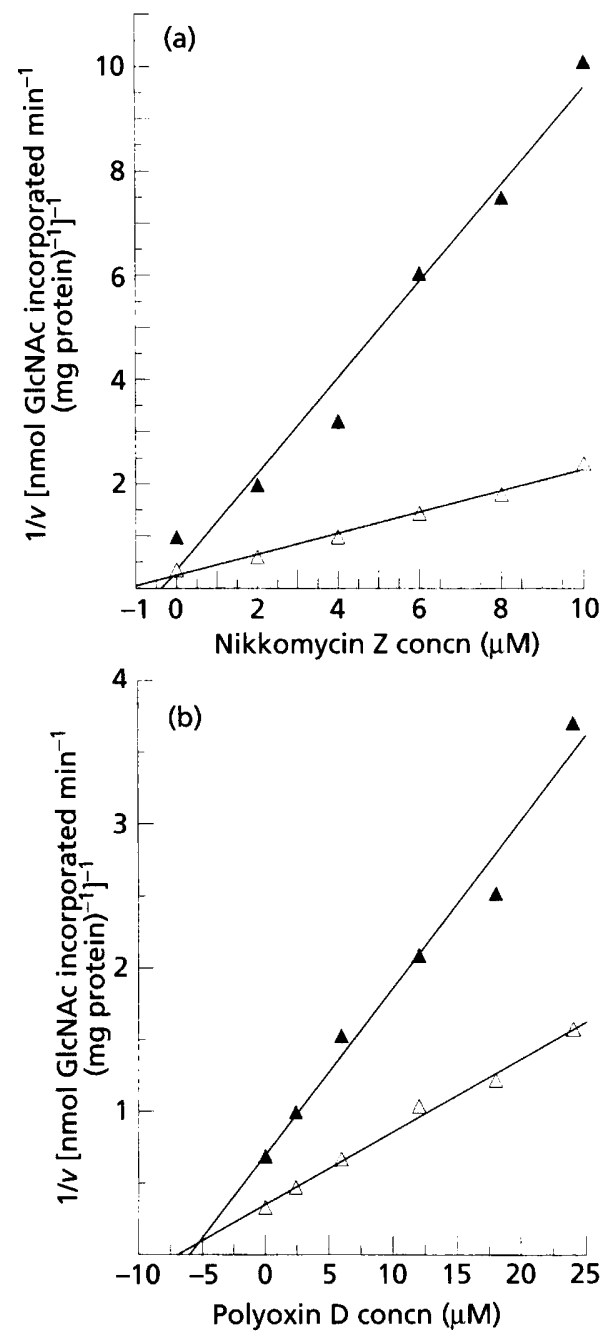

Fig. 4. Effect of nikkomycin $Z$ and polyoxin $D$ on chitin synthase activity in the presence of $0.5 \mathrm{mMUDP}-G \mid c N A c(\boldsymbol{\Delta})$, giving regression lines of $y=0.01 x+0.004(r=0.98 ;$ nikkomycin), $y=$ $0.001 x+0.007$ ( $r=0.98$; polyoxin), and $1 \mathrm{mM}$ UDP-GICNAC $(\triangle)$ giving regression lines of $y=0.002 x+0.002 \quad(r=0.98$; nikkomycin), $y=0.0005 x+0.004(r=0.99$; polyoxin).

and $6 \mu \mathrm{M}$, respectively (Fig. 4). Dixon plot analysis indicated that UDP inhibited competitively (apparent $K_{\mathbf{i}}$ of $190 \mu \mathrm{M}$ ) and the organophosphorus fungicide edifenphos was a non-competitive inhibitor (apparent $K_{\mathrm{i}}$ of $54 \mu \mathrm{M})$ (data not shown).

\section{Effect of pre-incubating microsomes alone or with trypsin or high-speed cytosol on chitin synthase activity}

A slight (maximum twofold) increase in chitin synthase activity was observed following incubation of microsomes $\left(0.3 \mathrm{mg}\right.$ protein $\left.\mathrm{ml}^{-1}\right)$ for $2 \mathrm{~h}$ at $25^{\circ} \mathrm{C}$. Microsomal chitin synthase was activated by trypsin; maximal activation (3.75-fold) occurred at a concentration of $25 \mu \mathrm{g}$ trypsin $\mathrm{ml}^{-1}$ (Fig. 5a). Pre-incubation with cytosol resulted in a 

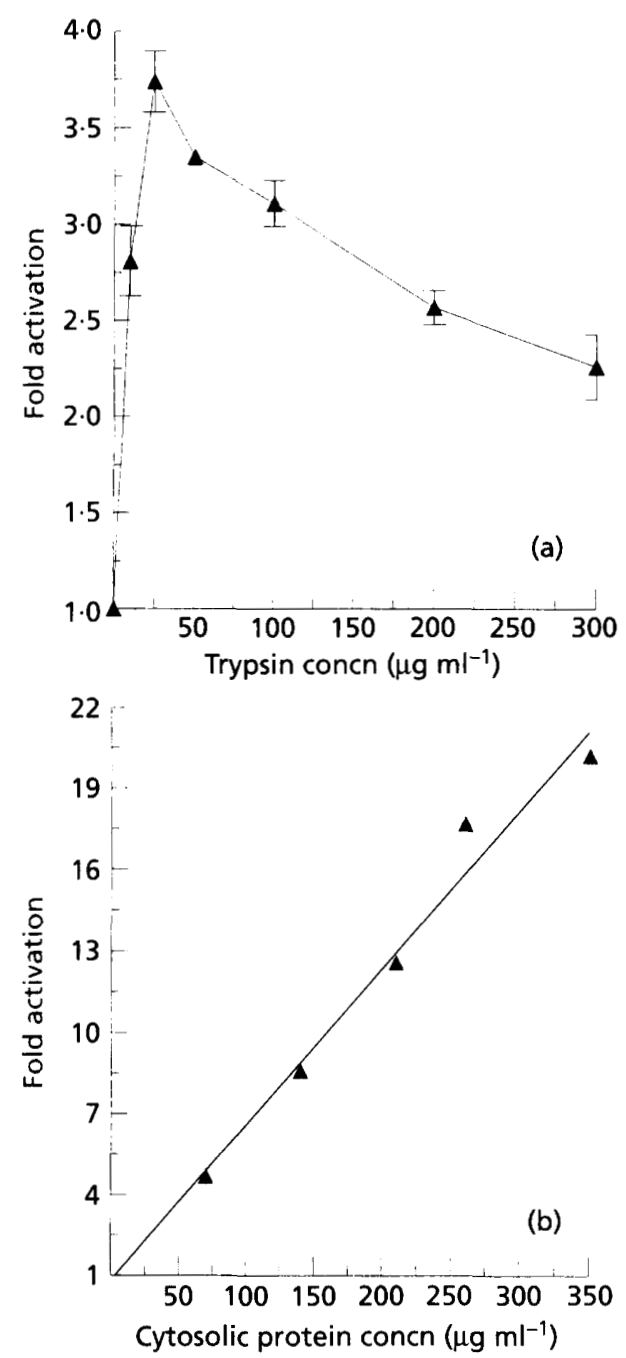

Fig. 5. Effect of trypsin (a) and concentrated cytosol (b) on microsomal chitin synthase. Microsomes were incubated with trypsin or cytosol as described in Methods, and assayed for chitin synthase activity. Values are based on a control incubation which did not contain trypsin or cytosol [activity in the control incubation was $2.8 \mathrm{nmol}$ GlcNAc incorporated min $^{-1}$ (mg protein) ${ }^{-1}$ ]. For trypsin incubations, values shown are the means of four experiments \pm SEM. For cytosol incubations, the experiment was repeated three times with essentially the same result.

20 -fold increase in chitin synthase activity at a concentration of $350 \mu \mathrm{g}$ cytosolic protein $\mathrm{ml}^{-1}$ (Fig. 5b). No chitin synthase activity was detected in cytosol prior to incubation with microsomes.

\section{Effect of protease inhibitors on activation of chitin synthase by cytosol}

All of the protease inhibitors reduced the degree of activation of microsomal chitin synthase by cytosol (Fig. 6). Most potent were PMSF and chymostatin; these compounds completely inhibited activation of enzyme activity.

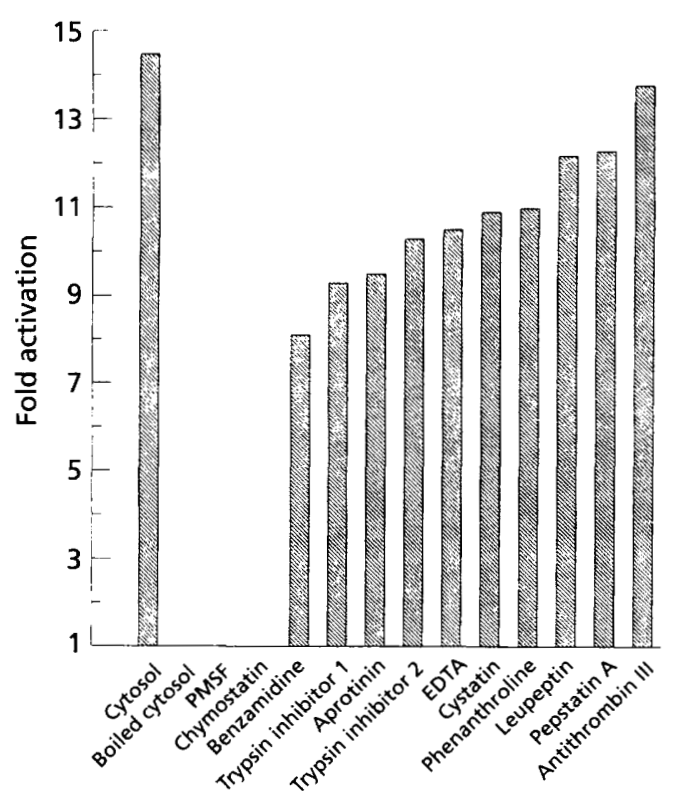

Fig. 6. Effect of protease inhibitors on the activation of chitin synthase by concentrated cytosol. Protease inhibitors (for concentrations, see Methods; trypsin inhibitors 1 and 2 were from lima bean and soyabean, respectively) were included in incubations of microsomes with cytosol (final concentration $200 \mu \mathrm{g}$ cytosolic protein $\mathrm{ml}^{-1}$ ) as described in Methods, and assayed for chitin synthase activity. Values are based on a control incubation which contained boiled cytosol. Activity in the control incubation was $2.8 \mathrm{nmol}$ GIcNAC incorporated min $^{-1}$ (mg protein $)^{-1}$. All assays were performed in triplicate and varied by less than $10 \%$. The experiment was repeated twice with essentially the same result.

\section{DISCUSSION}

Bowen et al. (1992) designed degenerate PCR primers based on two small regions of complete amino acid homology between the chitin synthase genes of Saccharomyces cerevisiae (CHS1 and CHS2) and Candida albicans (CHS1). The primers were used to amplify fragments (approximately $600 \mathrm{bp}$ ) homologous to chitin synthase from the genomic DNA of 14 fungal species. During the present study, similar primers were used to amplify fragments (approximately $600 \mathrm{bp}$; CHS1 and CHS2) from the genomic DNA of B. cinerea. When the DNA and predicted amino acid sequences of CHS1 were used to probe computer databases for related sequences, B. cinerea CHS1 was found to be most similar to CHS1 from $N$. crassa. Phylogenetic analysis of aligned amino acid sequences divided the sequences into three classes (data not shown). Sequences from like species grouped together within these classes in broad agreement with the results of Bowen et al. (1992).

The properties of microsomal chitin synthase from $B$. cinerea were similar to those of particulate chitin synthases from other fungi (for references, see Cabib, 1987; Machida \& Saito, 1993). It is important to note that chitinase and $\mathrm{N}$-acetylglucosaminidase activities were also detected in the $B$. cinerea microsomes. The specific activities of these 
enzymes were approximately one-tenth of the activities detected in cytosolic preparations. Nonetheless, the presence of chitinase and $N$-acetylglucosaminidase in chitin synthase preparations should be borne in mind as these enzymes may have influenced the results obtained during studies of enzyme kinetics. Apparent membrane-bound chitinases have been detected in a number of fungi (Adams et al., 1993), and Rast et al. (1991) proposed a model for the controlled lysis of chitin in the cell wall of Mucor rouxii, through the concerted action of chitin synthase with microsomal and cytosolic chitinase and $N$ acetylglucosaminidase activities. The apparent $K_{\mathrm{m}}$ for UDP.GlcNAc was approximately $2 \mathrm{mM}$ and enzyme activity [typically 3-4 $\mathrm{nmol}$ GlcNAc incorporated into chitin $\min ^{-1}$ (mg protein $)^{-1}$ ] was stimulated by free GlcNAc. High concentrations of GlcNAc were required for stimulation (Fig. 2); the physiological significance of this effect is unclear (Cabib, 1987). Polyoxin D and nikkomycin $\mathrm{Z}$ were potent, competitive inhibitors of chitin synthase in $B$. cinerea microsomes; the kinetics of inhibition closely resembled those reported previously for other fungi (reviewed by Gooday, 1990). Polyoxins have been used with some success in the treatment of fungal diseases of rice plants and black spot disease of pears (caused by Alternaria kickuchiana) in Japan (Hori et al., 1974c; Fiedler et al., 1982). Nikkomycins were active against $B$. cinerea growing on bean plants (Fiedler et al., 1982 ) and when $B$. cinerea was incubated with nikkomycin in vitro, the antibiotic inhibited spore germination and caused swelling of germ tubes (Zhu \& Gooday, 1992). During the current study, germ tube morphology was affected in a similar manner by polyoxin $\mathrm{D}(50 \mu \mathrm{M}$; data not shown).

The modulation of membrane-bound enzyme activities by alterations in membrane fluidity (which result from changes in the lipid composition of the membrane) is well-documented (Houslay \& Stanley, 1982). Chitin synthase is an integral membrane protein and, predictably, studies in vitro and in vivo suggest that the lipid environment may play a role in regulating enzyme activity (Adams et al., 1993). The organophosphorus fungicide edifenphos, which is thought to inhibit phosphatidylcholine synthesis in vivo (Kodama et al., 1980), reduced the incorporation of $\left[{ }^{3} \mathrm{H}\right] \mathrm{GlcNAc}$ into chitin in Fusarium graminearum (Binks et al., 1991). Furthermore, membranebound chitin synthase preparations from cultures of $F$. graminearum grown in the presence of edifenphos had much lower activities in vitro than preparations grown in the absence of the fungicide. Microsomal chitin synthase from $F$. graminearum was inhibited non-competitively by edifenphos with an apparent $K_{\mathrm{i}}$ of $50 \mu \mathrm{M}$. A similar result was obtained during the present study : microsomal chitin synthase from $B$. cinerea was inhibited non-competitively by edifenphos with a $K_{\mathrm{i} \text { app }}$ of $54 \mu \mathrm{M}$. As Binks et al. (1991) suggested, edifenphos may inhibit chitin synthase activity indirectly in vivo following an alteration in the phospholipid composition of the cell membrane. In addition, our results, and those of Binks et al. (1991) suggest that the fungicide may also affect chitin synthase activity directly.
Chitin synthase preparations from most species of fungi contain enzyme which may be activated by partial proteolysis. During the present study, limited proteolysis with trypsin increased chitin synthase activity approximately fourfold. One interpretation of this phenomenon is that, in vivo, regulation of localized chitin synthesis is achieved through synthesis of chitin synthase as a zymogen, with subsequent activation of the enzyme at the required time and place in the cell (Cabib \& Farkas, 1971). The results of Machida \& Saito (1993) appear to lend weight to this hypothesis. These authors purified a chitin synthase zymogen (molecular mass $30 \mathrm{kDa}$ ) from Absidia glauca. Incubation with trypsin converted the zymogen to an active enzyme $(28.5 \mathrm{kDa})$. Incubations of $B$. cinerea microsomes with cytosol from this organism caused a marked stimulation of chitin synthase activity (Fig. 5b). This effect was completely inhibited by the serine/cysteine protease inhibitors PMSF and chymostatin (Fig. 6). However, a wide range of compounds representing all of the major classes of protease inhibitor caused partial inhibition of chitin synthase activation by cytosol. These results suggest that many proteases endogenous to $B$. cinerea may, potentially, activate chitin synthase in vivo. Indeed, using ion-exchange chromatography, we identified a number of proteins in $B$. cinerea cytosol which activated chitin synthase zymogen in vitro (Adams et al., 1993). Furthermore, B. cinerea microsomes also appear to contain a factor which activates chitin synthase. To date, the nature of the endogenous proteolytic activator(s) of chitin synthase zymogen has not been determined for any fungus. If proteolytic activation is an important mechanism for the regulation of chitin synthase in vivo, then it is essential that the nature and sub-cellular location of the activator should be established, as such a protease would present an attractive target for novel fungicides.

\section{ACKNOWLEDGEMENTS}

We thank Dr Alan Radford for his help with computer databases and programs, and Dr John Pillmoor for useful discussions throughout the course of the work. We gratefully acknowledge the financial assistance of Schering Agrochemicals Ltd and the Science and Engineering Research Council.

\section{REFERENCES}

Adams, D. J. (1994). Drug and pesticide resistance in fungi. In Molecular Genetics of Drug Resistance. Edited by C. R. Wolf \& J. D. Hayes. London: Harwood Academic Publishers (in press).

Adams, D. J., Causier, B. E., Mellor, K. J., Keer, V., Milling, R. \& Dada, J. (1993). Regulation of chitin synthase and chitinase in fungi. In Chitin Enzymology, pp. 15-25. Edited by R. A. A. Muzzarelli. Ancona: European Chitin Society.

Backhouse, D. \& Willets, H. J. (1984). A histochemical study of sclerotia of Botrytis cinerea and Botrytis fabae. Can J Microbiol 30, 171-178.

Beynon, R. J. \& Salvesen, G. (1989). Commercially available protease inhibitors. In Proteolytic Enzymes. A Practical Approach, pp. 241-249. Edited by R. J. Beynon \& J. S. Bond. Oxford: IRL Press.

Binks, P. R., Robson, G. D., Goosey, M. W., Humphreys, A. \& 
Trinci, A. P. J. (1991). Chitin synthesis in Fusarium graminearum and its inhibition by edifenphos (Hinosan). J Gen Microbiol 137, 615-620.

Bowen, A. R., Chen-Wu, J. L., Momany, M., Young, R., Szaniszlo, P. J. \& Robbins, P.W. (1992). Classification of fungal chitin synthases. Proc Natl Acad Sci US A 87, 7424-7428.

Bradford, M. M. (1976). A rapid and sensitive method for the quantitation of microgram quantities of protein utilizing the principle of protein-dye binding. Anal Biochem 72, 248-254.

Cabib, E. (1987). The synthesis and degradation of chitin. Adv Enzymol 59, 59-101.

Cabib, E. \& Farkas, V. (1971). The control of morphogenesis: an enzymatic mechanism for the initiation of septum formation in yeası. Proc Natl Acad Sci US A 68, 2052-2056.

Cabib, E., Silverman, S. J. \& Shaw, J. A. (1992). Chitinase and chitin synthase 1: counterbalancing activities in cell separation of Saccharomyces cerevisiae. J Gen Microbiol 138, 97-102.

Causier, B. E. (1993). Chitin synthase of Botrytis cinerea. $\mathrm{PhD}$ thesis, University of Leeds.

Chen-Wu, J. L., Zwicker, J., Bowen, A. R. \& Robbins, P. W. (1992). Expression of chitin synthase genes during yeast and hyphal grou th phases of Candida albicans. Mol Microbiol 6, 497-502.

Cohen, E., Elster, I. \& Chet, I. (1986). Properties and inhibition of Sclerotitum rolfsii chitin synthetase. Pestic Sci 17, 175-182.

Dickinson, K., Keer, V., Hitchcock, C. A. \& Adams, D. J. (1989). Chitinase activity from Candida albicans and its inhibition by allosamidin. J Gen Microbiol 135, 1417-1421.

Dickinson, K., Keer, V., Hitchcock, C. A. \& Adams, D. J. (1991). Microsomal chitinase activity from Candida albicans. Biochim Biophys Acta 1073, 177-182.

Fiedler, H.-P., Kurth, R., Langhärig, J., Delzer, J. \& Zähner, H. (1982). Nikkomycins: microbial inhibitors of chitin synthase. $J$ Chem Tecbnol Biotechnol 32, 271-280.

Flemming, S., Cwielong, P. \& Huttermann, A. (1982). The cell wall of Fomes annosus (Heterobasidion annosum) as a target for biochemical control. 2. The influence of inhibitors of cell wall synthesis. Eur J Forest P'athol 12, 273-280.

Gooday, G. W. (1990). Inhibition of chitin metabolism. In Biochemiitry of Cell Walls and Membranes in Fungi, pp. 61-79. Edited by P. J. Kuhn, A. P. J. Trinci, M. J. Jung, M. W. Goosey \& L. G. Copping. Berlin: Springer-Verlag.

Gooday, G. W. \& Trinci, A.P. J. (1980). Wall structure and biosynthesis in fungi. In The Eukaryotic Microbial Cell, pp. 207-251. Edited by G. W. Gooday, D. Lloyd \& A. P. J. Trinci. Cambridge: Cambridge University Press.

Groves, J. D., Fox, R. T. V. \& Baldwin, B. C. (1988). Modes of action of carbendazim and ethyl N-(3,5-dichlorophenyl)carbamate on field isolates of Botrytis cinerea. Proceedings of the British Crop Protection Conference - Pests and Diseases, 1988, pp. 397-402.

Higgins, D. G., Bleasby, A. J. \& Fuchs, R. (1991). Clustal V: improved software for multiple sequence alignment. Comput $A p p l$ Biosct 8, 189-191.

Hori, M., Kakiki, K., Suzuki, S. \& Misato, T. (1971). Studies on the mode of action of polyoxins. Part III. Relation of polyoxin structure to chitin synthetase inhibition. Agric Biol Cbem 35, 1280-1291.

Hori, M., Kakiki, K. \& Misato, T. (1974a). Further study on the relation of polyoxin structure to chitin synthetase inhibition. Agric Biol Chem 38, 691-698.

Hori, M., Kakiki, K. \& Misato, T. (1974b). Interaction between polyoxin and active centre of chitin synthetase. Agric Biol Chem 38, 699-705.

Hori, M., Eguchi, J., Kakiki, K. \& Misato, T. (1974c). Studies on the mode of action of polyoxins. VI. Effect of polyoxin B on chitin synthesis in polyoxin-sensitive and resistant strains of Alternaria kikuchiana. J Antibiot 27, 260-266.

Houslay, M. D. \& Stanley, K. K. (1982). Dynamics of Biological Membranes. Infuence on Synthesis, Structure and Function. Chichester: John Wiley \& Sons.

Kodama, O., Yamashita, K. \& Akatsuka, T. (1980). Edifenphos, inhibitor of phosphatidylcholine biosynthesis in Pyricularia oryzae. Agric Biol Chem 44, 1015-1021.

Leroux, P. \& Clerjeau, M. (1985). Resistance of Botrytis cinerea Pers. and Plasmopara viticola (Berk. \& Curt.) Berl. \& de Toni to fungicides in French vineyards. Crop Prot 4, 137-160.

Locke, T. \& Fletcher, J. T. (1988). Incidence of benomyl and iprodione resistance in isolates of Botrytis cinerea in tomato crops in England and Wales in 1986. Plant Patbol 37, 381-384.

Lundblad, G., Hederstedt, B., Lind, J. \& Steby, M. (1974). Chitinase in goat serum: primary purification and characterization. Eur $J$ Biochem 46, 367-376.

Machida, S. \& Saito, M. (1993). Purification and characterization of membrane-bound chitin synthase. J Biol Chem 268, 1702-1707.

Murray, M. G. \& Thompson, W. F. (1980). Rapid isolation of high molecular weight plant DNA. Nucleic Acids Res 8, 4321- 4325.

Pommer, E.-H. \& Lorenz, G. (1982). Resistance of Botrytis cinerea Pers. to dicarboximide fungicides - a literature review. Crop Prot 1 , 221-230.

Rast, D. M., Horsch, M., Furter, R. \& Gooday, G. W. (1991). A complex chitinolytic system in exponentially growing mycelium of Mucor rouxii: properties and function. J Gen Microbiol 137, 2797-2810.

Sanger, F., Nicklen, S. \& Coulson, A. R. (1977). DNA sequencing with chain-terminating inhibitors. Proc Natl Acad Sci USA 74, 5463-5467.

Shaw, J. A., Mol, P. C., Bowers, B., Silverman, S. J., Valdivieso, M. H., Duran, A. \& Cabib, E. (1991). The function of chitin synthases 2 and 3 in the Saccharomyces cerevisiae cell cycle. J Cell Biol 114, 111-123.

Yarden, O. \& Yanofsky, C. (1991). Chitin synthase 1 plays a major role in cell wall biogenesis in Neurospora crassa. Genes \& Dev 5, 2420-2430.

Zhu, W.-Y. \& Gooday, G. W. (1992). Effects of nikkomycin and echinocandin on differentiated and undifferentiated mycelia of Botrytis cinerea and Mucor rouxii. Mycol Res 96, 371-377.

Received 3 February 1994; revised 17 March 1994; accepted 5 May 1994. 